\title{
"There is still peace. There are no wars.": Prioritizing unity over diversity in Botswana's social studies policies and practices and the implications for positive peace
}

\section{Citation}

Mulimbi, Bethany, and Sarah Dryden-Peterson. 2018. “'There Is Still Peace. There Are No Wars.': Prioritizing Unity over Diversity in Botswana's Social Studies Policies and Practices and the Implications for Positive Peace." International Journal of Educational Development 61 (July): 142-154.

\section{Published Version}

doi:10.1016/j.ijedudev.2017.12.009

\section{Permanent link}

http://nrs.harvard.edu/urn-3:HUL.InstRepos:34712315

\section{Terms of Use}

This article was downloaded from Harvard University's DASH repository, and is made available under the terms and conditions applicable to Open Access Policy Articles, as set forth at http:// nrs.harvard.edu/urn-3:HUL.InstRepos:dash.current.terms-of-use\#OAP

\section{Share Your Story}

The Harvard community has made this article openly available.

Please share how this access benefits you. Submit a story. 
"There is still peace. There are no wars.":

\title{
Prioritizing Unity Over Diversity in Botswana's Social Studies Policies and Practices and the Implications for Positive Peace
}

\author{
Bethany Mulimbi, Harvard Graduate School of Education \\ Sarah Dryden-Peterson, Harvard Graduate School of Education
}

Corresponding Author:

Sarah Dryden-Peterson

Harvard Graduate School of Education

6 Appian Way

Gutman Library 457

Cambridge, MA 02138 USA

Tel: 617-495-8162/ 617-435-2344

Email: sarah_dryden-peterson@gse.harvard.edu

\section{Acknowledgements}

We express our thanks to students, teachers, administrators, staff, and community members who welcomed us into their schools and communities; colleagues at the University of Botswana, especially Nkobi Owen Pansiri, Lydia Nyati-Saleshando, and Kelone Khudu-Peterson; research assistants at each site: Moyagabo, Mosenodi, Bopelo, and Kelebogile; and to Meira Levinson, Paola Uccelli, Elizabeth Adelman, Vidur Chopra, and the Mowana Lab for feedback on earlier drafts.

\section{Funding}

This work was supported by the Weatherhead Center for International Affairs at Harvard University; a Research Enabling Grant from Harvard University; the Fulbright program of the United States Department of State; a Sinclair Kennedy Traveling Fellowship and a Dissertation Completion Fellowship from Harvard University; and National Academy of Education/Spencer Dissertation Fellowship and Postdoctoral Fellowship. 


\section{"There is still peace. There are no wars.":}

\section{Prioritizing Unity Over Diversity in Botswana's Social Studies Policies and Practices and the Implications for Positive Peace}

\section{Introduction}

Since independence from Great Britain in 1966, Botswana has been celebrated as an example of enduring peace and democracy (Acemoglu \& Robinson, 2012; Moyo, 2009). Yet Botswana is not unlike the many other multiethnic states in Sub-Saharan Africa, in that it has faced the dilemma of how to negotiate ethnic diversity while promoting a sense of national unity. Botswana has followed a particular path: post-independence education policies promoted assimilation through construction of national identity as synonymous with the majority ethnic group's culture and language. Currently, however, just over fifty years after Independence, there are competing constructions of Botswana's national identity: assimilationist, rooted in the only slightly numerically dominant Tswana ethnic group, and multicultural, reflective of Botswana's more than 20 ethnic groups (Dryden-Peterson \& Mulimbi, 2017; Nyati-Ramahobo, 2006c).

These competing constructions are particularly visible in the expectations placed on the formal education system, which Botswana's post-independence government has long regarded as "potentially the most important single instrument for nation-building" (Republic of Botswana, 1977, p. 12). The assimilationist construction pervaded the first post-independence official education policy, Education for Kagisano (1977), which embraced the majority indigenous language, Setswana, and promoted the Tswana ethnic identity as the identity of all citizens, including members of numerous ethnic minority groups (Nyati-Ramahobo, 2006; Tabulawa, 1997). The multicultural construction emerged explicitly two decades later in Vision 2016, a 
Prioritizing Unity over Diversity in Botswana

document that articulated national goals for the $50^{\text {th }}$ anniversary of independence. This long-term vision document, which remains the blueprint guiding national development policies (Republic of Botswana, 2009), drastically departed from an assimilationist approach, stating, "[t]he education system will recognise, support and strengthen Botswana's wealth of different languages and cultural traditions" (Presidential Task Group for a Long-Term Vision for Botswana, 1997, p. 5).

Tensions between assimilationist and multicultural constructions of Botswana's national identity, as reflected in the education system, are not inconsequential for Botswana's continued stability and students' well-being. Policies promoting assimilation to a Tswana cultural and linguistic identity as the basis of Botswana's national identity may have contributed to national unity and, as a result, to Botswana's avoidance of ethnically-based violence (Dryden-Peterson \& Mulimbi, 2017; Gulbrandsen, 2012). This absence of violence is what Galtung calls "negative peace" (1969) which, despite the pejorative term, is nonetheless significant in a region where wide-spread violence has been the norm. And yet the comparatively poor academic performance and high school drop-out rates that many minority ethnic groups experience have been attributed to these same assimilationist school policies and curricula (Jotia \& Pansiri, 2013; NyatiRamahobo, 2006; Pansiri, 2012). Differential educational outcomes along ethnic lines, coupled with an ongoing lack of public recognition of minority ethnic groups (Dryden-Peterson \& Mulimbi, 2017), stand in the way of Botswana achieving "positive peace," or the absence of structural violence that could lead to equal opportunities (Galtung, 1969).

This article examines the extent to which education policy and practice in Botswana currently address issues not only of negative peace but also of positive peace. To do so, we analyze the ways in which social studies curriculum - as written in formal and nationally- 
Prioritizing Unity over Diversity in Botswana

approved syllabi and textbooks and as taught by teachers in classrooms - negotiate the tensions between the assimilationist and multicultural constructions of national identity found in policy. We find that the written curriculum continues to be assimilationist in approach, normed around the culture and language of the Tswana ethnic majority. At the same time, the curriculum promotes civic values that cut across ethnic groups, and it emphasizes the importance of national identity over ethnic identity. Irrespective of their own backgrounds or those of their students, teachers overwhelmingly adhered to the curriculum as written, citing ideological and practical reasons for doing so. We conclude by discussing whether the elements of national identity that teachers found salient in the written curriculum and prioritized in their classrooms are as relevant for goals of unity today as they were following Independence, as the potential for direct conflict has changed considerably and the need to establish conditions of positive peace are more urgent.

\section{Background: Ethnicity and Language in Botswana}

Although the name of the country indicates that Botswana is the home of the Tswana people, there are in fact many ethnic groups within the national borders. Social scientists have long cautioned against "groupism" - thinking of ethnicity as involving bounded groups whose members are homogeneous on various cultural markers, language, and worldviews. They argue instead for conceptualizing ethnicity as dynamic processes of social interactions and ways of interpreting the social world, while at the same time noting the natural human tendency and political usefulness of reifying ethnic groups (see, for example, Brubaker, 2009). These practices are common in policy rhetoric and school textbooks globally. Botswana is no different: curricular documents, stakeholder interviews, and lesson observations show a strong tendency towards such groupism, as opposed to more complex understandings of ethnic identity. 
Grounded in these data sources, our analysis takes these references to specific, named ethnic groups as units of analysis. We acknowledge, however, that individuals in Botswana may think about boundaries between ethnic groups and the nature of ethnic identity very differently.

The ethnic groups of Botswana are illustrated in Figure 1, organized by their linguistic relationships. The Constitution recognizes eight "major tribes" who share the common language, Setswana, and who live mainly in the south and east of Botswana (Nyati-Ramahobo, 2006b; Pansiri, 2012; Republic of Botswana, 2000). These eight Tswana groups constitute the majority in political and legal terms, while numerous politically unacknowledged but self-identifying nonTswana ethnic groups make up the minority. As is customary in English, we refer to this political majority ethnic group as Tswana, to all other groups as minority, and we reserve the term Batswana to connote all citizens of Botswana, regardless of their ethnicity.

Botswana's indigenous ethnic groups include non-Setswana-speaking minority ethnic groups who live throughout the country but are concentrated in the west and north (NyatiRamahobo, 2006b; Pansiri, 2012). Each of the Bantu groups speaks a unique language that is mutually unintelligible with Setswana but in the same linguistic family. These groups are not recognized in Botswana's Constitution. Also not recognized in Botswana's Constitution are members of Khoi and San groups, "first peoples" whose presence in the Botswana territory predates the Bantu groups, both Tswana and minority, by over 130,000 years (Denbow \& Thebe, 2006).

Policy-makers and minority rights advocates use widely varying population estimates of ethnic groups to represent Botswana as either ethnically homogenous or ethnically diverse, with claims ranging from 18 percent Tswana (Nyati-Ramahobo, 2006b; Nyati-Saleshando, 2011) to 80 percent Tswana (Republic of Botswana, 1977). The Afrobarometer survey is the only 
Prioritizing Unity over Diversity in Botswana

nationally representative data that includes self-reports of respondents' ethnicity. In the three years that include data on ethnicity $(2005,2008,2012)$, just over half of respondents identify as Tswana, and slightly under half identify as one of 21 other ethnic groups (Dryden-Peterson \& Mulimbi, 2017).

Minority groups in Botswana are diverse in terms of culture and language, historical migrations into modern-day Botswana, and political and economic standing. For example, the Kalanga - the largest minority group at around 11 percent of Botswana's population - have lived in the northeast of modern-day Botswana for at least five centuries, began their own postprimary schools as early as 1932 (Gossett, 1986, p. 349), and are well-represented in civil service and professional fields (Selolwane, 2004; Werbner, 2004). The pastoralist Herero - who constitute about one percent of Botswana's population - have lived mainly in the northwest of present Botswana only since the mid-1800s, with the largest influx fleeing the German genocide against them in modern-day Namibia around 1900 (Gewald, 1999).

Despite their varied historical experiences, minority ethnic groups have all long experienced geographical, political, or economic marginalization. In precolonial eras, many were in positions of serfdom within Tswana kingdoms (Gulbrandsen, 2012), and postcolonial investment and development has been concentrated in Tswana-dominated regions (Cook \& Sarkin, 2010; Leith, 2005). Furthermore, the Land Act of 1968 removed from Tswana chiefs the ability to allocate land, yet consolidated that power with Tswana political elites, effectively making land inaccessible to minority groups (Gapa, 2017). Until 2006, only the eight Tswana groups had constitutionally-granted political representation in the House of Chiefs (Republic of Botswana, 1966a), which serves an advisory role to democratically-elected government. Since the repeal of the Chieftainship Act in 2008, leaders from other geographic areas of the country 
have been included, with the total number of representatives now at 35 (Government of Botswana, 2008). This representation is the result of hard-fought and continuing battles for recognition, yet groups whose language is not Setswana continue to be unrepresented in this body (Gapa, 2017).

Ethnic minority advocacy has grown in Botswana over the past two decades. In the late 1980s and the 1990s, minority rights advocates began to question more forcefully the compatibility of these Constitutional arrangements with a liberal democracy. It was a time of formation of language and cultural groups and of advocacy, particularly in the area of language rights. The Kalanga have been what Werbner described as "the significant Other" for the Tswana in terms of economic influence (2004, pp. 71-85), yet they have not been alone in their assertion of cultural and political marginalization, especially in more recent years. In 1986, the Society for the Promotion of the iKalanga Language (SPIL) was formed; then, in 1995, the Kamanakao Association was formed "to develop and maintain the Shiyeyi language and culture, and to cultivate appreciation and knowledge among its speakers" (Nyati-Saleshando, 2011, p. 573); and in 1998, Lentswe la Batswapong was founded (Nyati-Ramahobo, 2006a) with an explicit aim of "try to get the Government teach our language [Setswapong] in schools" (Minority Voices Newsroom, 2010).

In 1999, then President Festus Mogae initiated an inquiry into certain sections of the Constitution on the grounds that they were discriminatory. The Commission found, in its 2000 report, that Batswana still self-identified along ethnic lines and believed that preference for the Tswana was ingrained in the Constitution itself. As the Commission's report related, those who criticized the Constitution as discriminatory "defined 'tribe' in non-territorial terms but rather in terms of such attributes as a distinct ethnic identity, shared culture, historical identity, and/or 
Prioritizing Unity over Diversity in Botswana

common language" (Republic of Botswana, 2000, p. 29). This understanding of "tribe" conveyed to the Commission that many citizens of Botswana considered cultural markers and language to be intimately tied to one's ethnic identity. They further "voiced their suspicion over the coincidence that all of the eight listed Tribes are Setswana speaking" (Republic of Botswana, 2000, p. 29). Setswana did not represent simply the national language, but the language of specific, privileged ethnic groups. The report reminded President Mogae that "many members of the public raised concerns about the said sections [77-79 of the Constitution] and advised that, if the Constitution was not amended, the long-term stability of this country, and in particular, the sustainability of its unity, could not be guaranteed" (Republic of Botswana, 2000, p. 9). However, these sections of the Constitution that were found to be discriminatory in 2000 have since remained unchanged (Nyati-Saleshando, 2011).

One piece of evidence used to document the discrimination was "educational and administrative policy that privileges the use of Setswana to the detriment of 20 minority languages, thereby denying the latter the opportunity to develop and enrich Botswana culturally" (Nyamnjoh, 2002, p. 760). Post-Independence, and in the name of national unity, the Government of Botswana banned the use of minority languages in public spheres including schools, the radio, the courts, and Parliament (Nyati-Ramahobo, 2006b). Setswana was declared the "national language," with English remaining the "official language" (Janson \& Tsonope, 1991).

Since the establishment of the post-Independence education system, Setswana has remained the language of instruction for the earliest years of primary school, after which instruction is carried out in English, with Setswana a compulsory subject through the end of senior secondary school (Republic of Botswana, 1994). Language of instruction policy has been 
a particularly contentious issue. When the most current education policy was drafted in 1993, the committee included a recommendation to offer primary school instruction in minority languages, yet this recommendation was rejected in the final policy because it was "counter to national language policy" (Republic of Botswana, 1994, p. 85). In this context, and with a lack of movement on rewriting Sections 77-79 of the Constitution, the Wayeyi tribe launched a direct challenge to the lack of minority right to representation. The group took a Constitutional challenge to the High Court of Botswana requesting, among other items, the right for children to be educated in their mother tongue. The High Court ruled in November 2001 that Sections 77-79 of the Constitution were discriminatory, but that discrimination along ethnic and linguistic lines was not prohibited by the Constitution. Indeed, Sections 3 and 15 of the Constitution protected against discrimination only on the basis of race, place of origin, political opinions, color, creed or sex (Republic of Botswana, 1966b). The Court cited not having enough information about the resource implications of the demand to teach minority languages in schools for their decision not to order the Government to allow this, resources requirements being outside the law (NyatiRamahobo, 2006a). While Setswana is the home language of the vast majority of households in southeastern Botswana, in northern and western districts - historically minority areas - many children enter school knowing little or no Setswana (Nyati-Ramahobo, 2006c).

\section{Conceptual Framework}

Since its Independence in 1966, Botswana has been characterized as the most peaceful nation-state on the African continent. In 2016, Botswana ranked 27 out of 163 countries on the Global Peace Index (Institute for Economics and Peace, 2017). This type of an index indicates the absence of violence, by measuring violent crime, homicide rates, and involvement in internal 
and external conflicts, for example. There are only four countries globally that have "no tensions with neighboring countries and have not recently been involved in any domestic or international conflicts" (Institute for Economics and Peace, 2017, p. 13). Botswana is one of them. This absence of violence in Botswana was improbable, as Botswana has exhibited many predictors of conflict: at Independence, it was among the poorest and least educated countries in the world, and it was surrounded by countries engulfed in civil war; its economy is based on natural resources, and it has high ethnic diversity with one dominant ethnic group. The freedom from violent conflict in Botswana is unique in the region.

Yet the absence of acute conflict is but one component of peace. In the field of peace studies, there is a useful and longstanding conceptual divide between the absence of personal violence, which Galtung called "negative peace," and the absence of structural violence, which he called "positive peace" (1969). We use Galtung's seminal definition of structural violence, to mean indirect violence where there is no actor who commits the violence and in which the violence adheres to structures and "shows up as unequal power and consequently as unequal life chances" (1969, pp. 170-171). Positive peace, therefore, is not only the absence of violence but the presence of conditions that allow individuals and groups to access equal opportunities. This conceptual distinction between negative peace and positive peace echoes current thinking in the practice of educational development as well. "Conflict transformation" agendas of organizations such as UNICEF build on the notion that being free from direct violence is only the first phase of building a lasting peace that is free from inequalities that may contribute to conflict or prompt a relapse into conflict (see, for example, Novelli \& Smith, 2011).

On the Positive Peace Index, Botswana does not rank as highly. Distinct from the Global Peace Index, this measure of positive peace focuses on attitudes, institutions, and structures: 
well-functioning government, equitable distribution of resources, free flow of information, good relations with neighbors, high levels of human capital, acceptance of the rights of others, low levels of corruption, and sound business environment. On this index, Botswana ranks 44 out of 162 countries, with lower scores on items such as equitable distribution of resources and acceptance of the rights of others (Institute for Economics and Peace, 2016, p. 43). Botswana is indeed highly unequal. Its Human Development Index score is 0.698 , but its inequality-adjusted Human Development Index is 0.433 , reflecting that almost 38 percent of national attainment in life expectancy, schooling, and income is lost to the unequal distribution of these resources. In education, 32.1 percent of human development is lost to this inequality, since years of schooling is widely divergent across individuals (United Nations Development Programme, 2016a, p. 45). Indeed, Botswana is one of the most unequal countries in the world; while the country ranks 108 out of 187 on human development, it falls 23 places when this human development is adjusted for inequality (United Nations Development Programme, 2016b, p. 207). These measures of inequality and positive peace in Botswana reflect other research that documents unequal access to power and opportunity in Botswana (Cook \& Sarkin, 2010; Dryden-Peterson \& Mulimbi, 2017; Gapa, 2017; Gulbrandsen, 2012; Nyati-Ramahobo, 2006c; Pansiri, 2012; Scanlon, 2002).

There are important ways in which Botswana has used policy, including in education, to disrupt certain kinds of inequalities, especially resource-based ones. For example, at Independence, only 20 percent of children were enrolled in primary school, yet by 1996, 96 percent of school-age children were enrolled in school with ten years of fee-free education (Dryden-Peterson \& Mulimbi, 2017). Botswana also had the first national HIV treatment program in Africa, and 87 percent of HIV-infected individuals are enrolled in antiretroviral therapy (ART), a greater proportion of people receiving effective therapy than even the best 
performing high income countries (Gaolathe et al., 2016). In a recent study, the most frequently provided definition of peace in Botswana was in fact "access to resources," with examples such as "when my children can go to school" (Malley-Morrison, 2013, p. 90). Wide-spread access to resources is an element of positive peace. Yet, following Galtung, we seek to understand the kinds of environments that might foster not only access to resources but equal opportunities to harness those resources and benefit from them.

One important such environment is education, in particular the ways in which schools promote or undermine positive peace. The construction of national identity in schools is one way to understand how children of the many ethnic backgrounds represented in Botswana may be included or excluded from the content of education. In line with Anderson (1983), we define national identity as a constructive act of imagination held collectively by citizens and perpetuated in official institutions, in this case, schools.

A state may adopt a range of policies meant to construct national identities that eliminate or manage ethnic differences. Two approaches, assimilation and multiculturalism both emphasize "full, equal membership in the state" through civic elements of national identity that can be acquired by all citizens no matter their ethnic origins (Kymlicka \& Norman, 2000, p. 14). Yet assimilation and multiculturalism differ in how they manage the content of these civic elements of national identity. Under an assimilationist approach, majority practices, often with ethnic foundations, are conceived as the civic norm, while also masquerading as neutral by virtue of the possibility of members of any ethnic group adopting them. At the same time, assimilationist policies refuse to acknowledge minority practices, religions, or languages or accord them recognition or support in public schools, institutions, national holidays, or other public spaces. Policies promoting multiculturalism, on the other hand, acknowledge that ethnic 
identities will continue to exist and must be recognized and accommodated within public institutions, including schools. Under this approach, unity is achieved through multiple and/or superordinate identities (see, for example, Gaertner \& Dovidio, 2000; Niens \& Chastenay, 2008) that coalesce around civic elements such as national principles, symbols, or equal rights, that are purposefully distanced from ethnic elements.

A state may also adopt assimilationist and multicultural policies at different points in time, depending on the intended purposes and the historical moment. For example, in both South Africa and Rwanda, textbooks in post-apartheid and post-genocide eras, respectively, have focused heavily on ideas of a united nation (Lerch, Russell, \& Ramirez, 2017) to overcome past divisions and promote basic conditions - such as lack of overt physical violence - in which equitable opportunities might be created. South Africa has taken a guarded multicultural approach, through the domination of "race-neutral discourses" and commitment to include "both sides of the story," in a way that may prevent violence but often de-racializes and de-historicizes the experiences of individuals and groups (Teeger, 2015). In Rwanda, education has focused on the creation of new and superordinate identities that can be inclusive by blurring individual and group differences (King, 2014) but which limit space for any "productive conflict" (Freedman, Weinstein, Murphy, \& Longman, 2008). History curriculum, for example, is based on one official historical narrative, developed among Tutsi refugees living in exile and which prioritizes unity of the collective with "no room for any kind of ethnic identification" (Freedman et al., 2008, pp. 674-675). As Christie (2016) encourages, we acknowledge in our analysis that varied social practices, including related to assimilation and multiculturalism, interact with each other and at different moments in time, especially in times of complex social change and with threat or experience of conflict. 
One key mechanism for disseminating national identity, in either approach, is through the use of historical narratives in formal history and social studies curriculum (see, for example, Bellino \& Williams, 2017; Freedman et al., 2008; Paulson, 2015). Billig (1995) reminds us that the nation is also continually flagged in schools through symbols that go largely unnoticed - the national flag, pictures of presidents, coats of arms, national maps - and through habits of speech in which "we" and "them" are not specified but understood to refer to who is included in the nation and who is not. In the course of explaining what it means to be included in the nation, schools also teach students to attend to identity markers that allow one to recognize members of a specific ethnic group, nation, religion, etc. (Bekerman \& Zembylas, 2012).

Debates around the dissemination of national identity through formal schools often center on the role of such identity markers, and critiques concern assimilationist constructions of national identity that promote majority groups' traditions, language, and historical understandings to the exclusion of minority groups. Some scholars within Botswana have called for multicultural education policies to combat the exclusionary construction of national identity they perceive in curriculum and to promote equitable educational outcomes for minority groups (Boikhutso \& Jotia, 2013; Lubinda, 2010; Nyati-Saleshando, 2011; Pansiri \& Jotia, 2013). Yet, as Banks (2001) points out, multicultural education encompasses a wide spectrum of practices, from simple acknowledgement of some contributions of minority group members, on the one hand, all the way to a social action approach that challenges assumptions of existing mainstream culture and encourages students to take action on social issues such as inequality and discrimination, on the other. The kind of multicultural education that enables what he calls "recognized citizenship," echoes the idea of positive peace, in that individuals are "structurally integrated into the nation-state, have strong identities with it, ... [are] publically identified and 
validated as citizens, and have the opportunity to fully participate in the polity" (Banks,

Forthcoming). Might these more intensive approaches to multicultural education, leaning toward conditions for positive peace, hold promise in improving educational outcomes and cultural and political recognition for students from minority groups, by allowing them to recognize themselves in the curriculum and feel empowered as equal members of the nation?

\section{Methodology}

\subsection{Research Approach}

The data for this study comes from interviews with social studies syllabus and textbook authors, document analysis of current Junior Secondary School (JSS) social studies syllabus and textbooks, and lesson observations, fieldnotes, and interviews with social studies teachers in four case study schools. We chose to focus on social studies given that this subject area explicitly aims to teach students about the society in which they live and their role in that society. A required school subject charged with teaching students "the ideals upon which the nation of Botswana is built" (Republic of Botswana, 2010, p. i), the social studies curriculum allows unique insight into the extent to which increasingly multicultural policy discourse makes its way, or not, into the construction of national identity being disseminated to students. It is particularly important to examine the curricular construction of national identity at the JSS level. As the final three years of Botswana's largely free ten-year basic education program, JSS marks the endpoint of formal education for most of Botswana's citizens (UNICEF, 2013). It also represents a developmental stage in which individuals are concerned with their identity in relation to a larger society beyond their family (Erikson, 1968) and at which education related to citizenship and national identity is most effective (Galston, 2001). We focus on the first two years of JSS, Form 
1 and Form 2, choosing not to include the third year, because the curriculum in that year focuses mainly on global content.

We examine the writing style and content of the JSS social studies curriculum, perspectives of curriculum authors and teachers, and lesson observations in junior secondary schools to determine how Botswana's school curriculum currently approaches constructing a unified national identity in the presence of ethnic diversity. Does the curriculum adopt a multicultural approach or does it continue to promote assimilation? In particular, we focus the inquiry on sections of the curriculum essential to constructing a national identity through schools - the historical narrative, identity markers of national citizens and specific ethnic groups, and national symbols and principles.

We further consider how the written curriculum in Botswana may be implemented by individual teachers serving in diverse schools. Sociologists have shown that ethnic elements of national identity hold more salience for individuals across nations than do civic elements (Jones \& Smith, 2001), but that individuals of minority backgrounds favor civic elements (Kunovich, 2009). Individual teachers, therefore, may emphasize elements of the written curriculum or introduce content and perspectives from outside the textbooks based on those elements of national identity most meaningful to them. Teachers who enjoy considerable autonomy in implementing curriculum may be more likely to adapt their construction of national identity in the classroom according to their own perspectives or their perceptions of their students' needs than those teaching in contexts of more centralized curriculum or higher accountability to teach a curriculum with fidelity (see, for example, Gozik, 2012). Which elements of national identity teachers in Botswana's schools emphasize in classroom instruction may depend in part on their own ethnic background, their awareness of growing public debate about minority group 
recognition, the relative value they place on civic elements of national identity, and the amount of autonomy they hold over curricular decisions.

\subsection{Methods}

To analyze the content of the written social studies curriculum, we coded the current (2010) JSS social studies syllabus at the learning objective level, identifying portions of the curriculum related to the historical narrative, cultural markers, or national symbols and principles. We arrived at nine relevant units and eleven relevant objectives across Forms 1 and 2. The units included, for example, "Social and Cultural Environments," "History and Foreign Relations," and "Civics"; and the objectives included, for example, "trace the origins of Batswana," "understand cultural diversity in Botswana," and "understand citizenship in Botswana and display a sense of patriotism." These objectives guide the organization and content of the textbooks, as well as indicating which information is assessed on national exams. Our textbook analysis focused on the social studies textbooks for Forms 1 and 2, first published by Collegium Publishers in 2009 and 2010, respectively (Moswang, Tsayang, \& Rampha, 2010; Tsayang, Rampha, \& Mpitse, 2009). These are centrally-approved social studies textbooks for use at the JSS level across all districts of Botswana. The books are written in English and contain frequent Setswana translations of words and phrases.

We analyzed textbook sections that corresponded to the objectives identified when coding the JSS social studies syllabus. For example, to compare how textbooks represent minority ethnic groups versus the majority Tswana, we analyzed sections discussing Botswana's regional lifestyles, indigenous knowledge systems, cultural heritage, the origins of Botswana's peoples, and more recent history of Botswana. To analyze how the books described ethnic identity vis-à-vis national identity, we coded sections of the civics units that discuss national 
principles and symbols and the roles of citizens in Botswana. We used codes such as "equity ethnic," meaning "equity or fairness between ethnic groups" and "identity - national," meaning "referencing a national identity, or describing what it means to be a Botswana/Batswana citizen." We coded identified textbook sections at the line level, and we did not code other sections of the textbooks.

Following Selander (1990), we focused on the "(a) selection of facts and themes; (b) style of writing and composition and (c) the combination of cognems and explanations" in textbooks (p. 147). In the selection of facts included in the textbooks, we examined whose languages, traditions, and knowledge systems are present and whose are absent. We also looked quantitatively at the coverage of minority versus majority groups in the text and images, as well as references to national identity versus ethnic identity, as suggested by Pingel (2010). We further considered how the textbooks' activities, chapter summaries, and practice questions orient the reader to which knowledge is most important to master. In style of writing and composition, we considered the extent to which the textbooks treat different ethnic groups with respect and tolerance, for instance whether the books offer description or judgment of lifestyles and perspectives. We also examined the importance the textbooks ascribe to ethnic versus national identities. In examining both cognems and explanations, we considered whether information or explanation is prioritized, as well as whether explanations take into account multiple perspectives. We specifically looked for explanations offered related to why Botswana's ethnic groups may hold different perspectives or practice different lifestyles, and what makes Botswana a 'nation' and its people 'national' citizens.

To illuminate how decisions about the current social studies curriculum were made, we conducted two interviews with curriculum writers. We asked a member of the social studies 
curriculum committee within Botswana's Ministry of Education about the processes the committee follows when reviewing the curriculum every five to ten years. We asked a textbook author what guidance she receives and how much flexibility she has when deciding the content of the textbooks.

To further understand how social studies curriculum is taught in schools across Botswana, we conducted ethnographic case studies of four junior secondary schools between February and September 2015. We selected schools located in four different districts, two in predominantly minority districts (Northwest and Northeast Districts) and two in predominantly Tswana districts (southeastern districts), in order to examine how curriculum may be implemented differently in schools situated within communities that differ in their ethnic composition. We further selected the schools to represent a wide range of characteristics typical of junior secondary schools in Botswana, in terms of size, rural/urban location, and boarding/day facilities. We have given these schools the pseudonyms Metsi, Ami, Vula, and Molapo, meaning rain/water/stream/waterfall in languages commonly spoken among students at the schools (see Table 1). Across the four schools, we conducted 25 observations of social studies lessons. We focused these observations on any content related to national or ethnic identity, following or deviating from the curriculum and textbook, languages in use, and interactions between teachers and students. We also conducted semi-structured interviews with 11 social studies teachers, 8 of whom were female and 3 of whom were male (see Table 2). We asked them about, for example, their own identities, their views on goals of multiculturalism stated in policy documents, their views on the curriculum specifically as related to what defines Botswana as a nation, and the kinds of lessons they find effective at teaching students what defines Botswana as a nation and how to be good citizens, and their views on teaching diverse students. Finally, we documented 
daily informal conversations with teachers through fieldnotes. This data collection was part of two larger studies that also included interviews with thought leaders and policymakers, observations of moral education classes, interviews with school administrators and moral education teachers, focus groups and interviews with students, and participatory action research in the case study schools. Our research was approved by the Institutional Review Board of [omitted for blind review] and conducted under permits [numbers omitted for blind review] issued by the Botswana Ministry of Education and Skills Development.

We coded lesson observations at the level of an utterance by a single speaker, qualitatively for content and quantitatively for the speaker, questions versus statements, and type of content, with a specific focus on understanding the alignment between the curriculum, textbook, and classroom instruction. From transcripts of the teacher interviews and conversations summarized in fieldnotes, we thematically coded excerpts that discussed 1) which content teachers are expected to teach to students, 2) which content teachers usually present to students, 3) which content the teacher felt was missing from the curriculum, or 4) the speaker's explanation or rationale of these content decisions and practices.

\section{Findings}

Our curriculum and textbook analysis reveals a mainly assimilationist construction of Botswana's national identity, albeit with some acknowledgment of contributions of minority ethnic groups. Tswana cultural norms and historical understandings dominate the cultural components of national identity as described in the textbooks, while the texts also include a strong emphasis on civic components that transcend any ethnic group. In interviews, curriculum writers described the conscious decisions over decades, and still in force today, to emphasize 
civic national ideals for the sake of building a peaceful nation, and to focus on tolerance more than detailed knowledge of ethnic diversity. Our school-based research reveals the salience of curriculum and textbook-based conceptions of national identity: in lesson observations, teachers demonstrated exceptionally high fidelity to the curriculum as written, regardless of their diverse ethnic backgrounds, with teachers offering a variety of pragmatic and ideological reasons for this choice during interviews.

\subsection{Cultural and Historical Bases of National Identity}

Based on Vision 2016's charge to the education system to recognize, support, and strengthen Botswana's diverse ethnic groups, we would expect the social studies textbooks to include content drawn from across ethnic groups and a writing style that conveys to learners the equality of these ethnic groups within Botswana. Instead, through clear assumptions about the norms of Botswana society, the textbooks implicitly establish Tswana history, culture, and language as core elements of Botswana's national identity. Minority ethnic groups are sometimes singled out as 'others' who deviate from the Tswana norm, but generally receive scant attention. Moreover, textbook units focusing on history and cultural sites reimagine the heritage of distinct ethnic groups into a national identity dominated by Tswana perspectives.

Throughout the textbooks, readers encounter more direct references to Tswana culture and historical Tswana individuals and groups than to all other ethnic groups combined. Whereas the textbooks confine content drawn from minority ethnic groups almost exclusively to three chapters on cultural diversity and pre-colonial history, they integrate knowledge of Tswana groups and Setswana phrases into every chapter analyzed in this study, on topics as diverse as traditional initiation and marriage ceremonies, expectations for family life, environmental 
Prioritizing Unity over Diversity in Botswana

conservation practices, proverbs governing morality, and the roles of chiefs and traditional courts in present times.

In some cases, the elements of heritage referenced are sufficiently broad as to include all indigenous ethnic groups. For example, the book states, "The Batswana languages are rich in proverbs (diane) and some wise sayings (maele) meant to help people develop good morals and also meant to entertain" (Moswang et al., 2010, p. 78). In most cases, the books do not make clear the specific Tswana origins of cultural heritage that they present as 'common.' For example, when discussing beliefs and practices that form cultural heritage, the Form 2 book avoids specifying ethnic origins and creates the impression of shared traditions by using the term for all citizens, Batswana. At other times, it creates a sense of common customs by dropping the subjects of its sentences, slipping into passive voice:

Traditionally there are foods that children are not supposed to eat, for example, domestic animals kidneys (diphilo tsa diruiwa) and chicken eggs (mae a dikoko). Bogwera and bojale (boys and girls initiation schools) are practiced by different groups of people (Moswang et al., 2010, p. 79).

Although bogwera and bojale are Tswana initiation practices, by dropping the subjects of these sentences, the textbook remains ambiguous about their origins.

This use of Batswana as the subject or employment of the passive voice fits a larger pattern across both textbooks. The textbooks frequently discuss "the traditional society," as opposed to various different traditional societies. For example, the Form 1 book discusses a singular tradition when describing indigenous knowledge systems, traditional marriage, and traditional gender roles, respectively. The specific practices these chapters describe, as pointed out earlier, are overwhelmingly Tswana in origin and distinct from the practices of other ethnic 
groups, although this is masked by the ambiguity of the term Batswana, which can refer to the specific ethnic group or all national citizens.

In addition to promoting Tswana traditions as the traditions of all Batswana, the textbooks uphold Setswana's status as the "national" language and norm from which other languages deviate. For example, when describing language as a characteristic on which Botswana's ethnic groups differ, the Form 2 textbook reads: "Different ethnic groups speak different languages in Botswana... The languages are different from Setswana" (Tsayang et al., 2009, p. 81). Setswana words or phrases are frequently included as translation for the predominantly English text, while no other indigenous languages are used. Neither textbook discusses how Setswana became the national language, treating it as a given that needs no explanation. Across both textbooks, highly unequal content coverage and the texts' assumption of Tswana language and lifestyle as norms for all readers combine to form a JSS curriculum still dominated by Tswana culture.

Both the Form 1 and Form 2 books do acknowledge a wide variety of ethnic groups living in Botswana. References to each non-Tswana Bantu ethnic group range from four (Basubiya) to ten (Kalanga) total excerpts, concentrated almost entirely in the fifth chapter of each book. The Form 1 chapter, "Environment and Humanity," describes each environmental zone in turn, explaining which ethnic groups live in each environmental zone of Botswana and the traditional homes, food production, crafts, and clothing to be found in that region. For example, the introduction to the section on the deciduous forest zone (northern Botswana) reads: Various ethnic groups inhabit the deciduous forest environmental zone. Some of these groups are the Wayei, the Hambukushu and the Herero as well as some Batawana, Basarwa [KhoiSan] and the Basubiya. The traditional way of life of 
these various groups have been influenced by the environment ... (Tsayang et al., 2009, p. 70).

The descriptions of lifestyles that follow each such introduction do not further distinguish between ethnic groups within each region, with the exception of the Khoi and San, whose nomadic lifestyles are singled out as different from all other groups. While most ethnic groups are named and given a regional location in this chapter, specific elements of lifestyle or culture are not attributed to any ethnic group.

The Form 2 chapter, "Cultural Diversity in Botswana," on the other hand, provides isolated information on cultural practices specific to a wider variety of ethnic groups. For example, students learn that Herero women wear a distinctive dress and pointed hat, seeing a photograph to illustrate this point. The Kalanga, they learn, prefer to eat millet meal. In their cultural diversity chapters, the texts provide extremely limited information about non-Tswana ethnic groups, serving to illustrate the influence of the environment on human lifestyle and the presence of cultural diversity, rather than to supply substantive knowledge about the customs, beliefs, or languages of any of these groups. The textbook author explained the decision to include some content drawn from these ethnic groups as follows:

We were looking at the fact that children are from different parts of the country, so you can have a name of plant [from] that side, and then somebody else will call it a different name, so we will try to bring in a local flavor. Or even their livelihoods, how they live, what they live on. So we try to bring in a little of the language of those people. (Interview 2, 11 July 2013)

While the textbooks do bring in some "local flavor" drawn from a variety of minority ethnic groups, in their structural elements, the textbooks signal that knowledge of these ethnic groups 
should be considered supplementary, not essential for mastery. Activities and exercises within the text, available to be used at each teacher's discretion, allow students to share their prior knowledge of any ethnic group's practices, as when they ask students to "make a list of traditional dancing styles that you know about" (Moswang et al., 2010, p. 84). Conversely, the revision questions, which assess students' knowledge of the main objectives and prepare them for exams, focus on the need to conserve the environment and the instrumental value of culture. Form 2 essay questions ask students to: "Discuss how various elements of culture bring about individual and national identity" and "Discuss the importance of culture in a society" (Moswang et al., 2010, p. 93). From these revision questions, students are reminded that culture is valuable for giving an individual or nation, but not an ethnic group, a sense of identity. While inculcating in readers these values of cultural diversity, the textbooks do little to promote knowledge of this diversity.

While Botswana's social studies textbooks do give some acknowledgement of cultural diversity in Botswana, they fall short of Vision 2016's multicultural goal to "recognize, support, and strengthen" ethnic groups. The scant attention devoted to non-Tswana groups does not recognize and support these groups' cultural characteristics as essential to Botswana's national identity. Tswana culture, on the other hand, remains central to the national identity. The social studies syllabus committee member explained that "We have, over a period of time, accustomed to the Setswana practices" (Interview 1, 29 July 2013). Culture described in the textbooks as ‘common' for Botswana's citizens, such as traditional marriage, national language, chieftaincy, and traditional courts is, indeed, overwhelmingly reflective of Tswana practices.

As the textbooks construct Botswana's national identity as primarily Tswana, their units on history and cultural sites recast potentially divisive ethnic histories into a singular history of a 
united Batswana populace. The chapters on Botswana's history, found mostly in the Form 2 book, paint a picture of an internally harmonious nation threatened by a series of external enemies and led to independence and beyond by national heroes. While a chapter on the earliest, prehistoric interactions between the Bantu and KhoiSan ends with "the Bantu driving the $[\mathrm{K}]$ hoesan people into the western part of Botswana ([K]galagadi desert)" (Moswang et al., 2010, p. 164), nowhere in the five further chapters on Botswana's history do the books mention any animosity between ethnic groups within Botswana. The books instead focus on a series of conflicts with external enemies. While insisting on a long history of internal peace may support the importance of peace and unity in Botswana's national identity, these accounts fail to recognize minority groups' historical perspectives well-documented elsewhere and thereby miss opportunities to promote positive peace.

\subsection{Building a Common Civic National Identity}

While the social studies textbooks encourage assimilation to Tswana norms and historical understandings, they also devote great attention to civic building blocks of Botswana's national identity, specifically drawing upon national principles, the electoral system, and national symbols. The textbooks regularly invoke kagisano (social harmony) and Botswana's five national principles (botho, ${ }^{1}$ democracy, development, self-reliance, and unity) as they discuss elements of national commonality. Most of the focus on national symbols, values, and goals falls in the textbooks' civics units, which ask students explicitly to conceptualize the world using national rather than ethnic frames of reference. One Form 1 objective asks students to "recognise the significance of national identities over ethnic identity" (Tsayang et al., 2009, p. 181). In their descriptions of national principles and goals and some of the symbols to which they are 
connected, the books avoid making reference to ethnicity, only occasionally including Setswana phrases and traditional Tswana activities to support these elements.

Both books employ national principles to frame their discussion of the overarching national goal of kagisano (social harmony). When introducing kagisano and the five national principles in its civics unit, the Form 1 book explains how citizens should understand and use these principles:

Botswana has a set of principles which are used to guide every Motswana on what is expected of them.... The nation of Botswana expects every citizen to have a positive attitude towards his fellow men. A positive attitude brings about social harmony or kagisano amongst the people in any given community. This develops tolerance to the differences that exist between people (Tsayang et al., 2009, p. 176).

This passage positions the nation, Botswana, as an entity capable of holding expectations for the behaviors and mindsets of "every Motswana" (individual citizen). Moreover, this paragraph aligns with Vision 2016's assertion that "Botswana must rediscover a collective identity based upon shared values and a respect for ethnic or cultural differences, or differing views or religious beliefs" (Presidential Task Group for a Long-Term Vision for Botswana, 1997, p. 23). The textbook passage promotes the shared value of kagisano as the means by which to develop tolerance for difference.

Indeed, so essential is kagisano to Botswana's national identity that an entire chapter of the Form 1 textbook is devoted to this concept. The introduction explains that "Kagisano is the national principle that guides governance in the country" (Tsayang et al., 2009, p. 181), and the chapter relates each of the national principles to kagisano. The multiple passages that explain the 
national principles and kagisano serve to paint a picture of intimately interrelated national values, which individual citizens should embody. By focusing on Botswana's broad national principles, the textbooks effectively convey civic ideals that do not privilege any ethnic group over another.

The Form 1 and Form 2 textbooks also describe how national symbols support a sense of national identity and pride. The Form 1 kagisano chapter explains:

Botswana has national slogans and symbols which identifies it to other countries in the world. The people of Botswana recognize the symbols and slogans because they give them a sense of belonging, identity and pride, protection, responsibility and loyalty and most of all the love for the country (Tsayang et al., 2009, p. 184). The chapter goes on to introduce the flag, passport, national language, currency, national anthem, and coat of arms as national symbols. The textbooks explain the meanings of these symbols and important public holidays not through reference to their origin with any particular ethnic group, but by again invoking the national principles. The Form 2 book describes the origins and content of the national anthem, highlighting the importance of cooperation for development, as well as peace: "[The national anthem] encourages citizens to be committed and to work cooperatively together towards the country's development. The song encourages citizens to keep peace in the country” (Moswang et al., 2010, p. 180). Both textbooks include activities asking students to demonstrate their evolving understanding of various national symbols. An activity in the Form 2 book, for example, asks students to sing the national anthem and then "Identify the key words which show the elements of national identity" (Moswang et al., 2010, p. 88). In both the main text and included activities, the textbooks provide opportunities for students to engage with important national symbols and understand their relationship to national principles and goals. 
Prioritizing Unity over Diversity in Botswana

As another civic element of Botswana's national identity, the textbooks celebrate the equal rights and responsibilities bestowed on individuals by virtue of being citizens of the nation. The textbooks very rarely position ethnic groups as actors and never as entities that could be granted group-level rights. Indeed, in its definition of "law," Chapter 12 of the Form 1 textbook establishes the value of individual-level rights and highlights the dangers of law which could be construed as privileging any group:

The law defends the rights of all equally. If by any chance it is applied unequally to one class of people over the others, the law turns from being an instrument of protection to being an instrument of oppression (Tsayang et al., 2009, p. 174). In this instance and many others, this chapter praises Botswana's liberal democracy in which "everyone is equal before the law" (Tsayang et al., 2009, p. 174) and every citizen "is regarded as an equal to all" (Tsayang et al., 2009, p. 177). In this respect, the textbooks are celebrating civic aspects of Botswana's national identity and explicitly establishing citizenship, not ethnicity or race, as the basis of membership in the nation. Through their emphasis on individuals and nations as actors, the textbooks sideline ethnicity and its cultural signifiers as potentially important sources of identity.

Taking the social studies syllabus as their framework, the textbooks convey the overarching importance of Botswana's national principles and especially kagisano, to Botswana's national identity. These principles are broad enough in their scope to supersede value systems of individual ethnic groups. Linking these principles to equally appealing goals of a harmonious, peaceful, and economically-developed nation, the textbooks then use these values and aims as the basis of civic national symbols (e.g. national anthem, flag, coat of arms), rather than historical symbols which are far less ethnically neutral. 


\subsection{Curriculum Implementation}

Observations of 25 social studies lessons across four junior secondary school sites in Botswana revealed that teachers overwhelmingly adhered to the curriculum as written in the syllabus and textbooks. Neither teachers' own backgrounds nor the ethnic composition of the student population that they served affected this consistently high level of fidelity. Table 3 presents the type of instructional content observed during these lessons, with a particular focus on how closely each statement or question aligned with the curriculum as written.

On average, just over half of all classroom utterances were direct reflections of the content found in the textbook or exam paper being used during the lesson. In these cases, the teacher or student was reading from the text or reciting the text verbatim. A further 19 percent of class utterances were explanations of what the text had stated, and 7.2 percent were examples that illustrated the text's point but were not found in the text. In total, approximately 75 percent of all lesson content observed directly matched or supported through additional examples, the written curriculum. This stands in stark contrast to instances in which a teacher or student brought up a concept not found in the text (3.2 percent) or offered an opinion on the content of the text ( 0.6 percent). These patterns largely held true across observations in different schools, with one exception being the comparatively large proportion of time in Metsi School spent on content unrelated to the curriculum (e.g. classroom management) or reflecting on the learning process (e.g. stating objectives and whether they have understood).

In one lesson, the teacher asked students to describe the effects of European hunters and traders in Botswana, a sub-section of the chapter they were working from. Below, our lesson observation notes of this lesson show the typically strict adherence to the content of the social studies textbook: 
Student 1: Decline of wild animals [exact wording from bold heading in book]

Teacher: [explains in his own words in English]

Student 2: New source of power for dikgosi [chiefs; exact wording from bold heading in book]

Teacher: Who can explain that?

Student 3: [Reads word-for-word from paragraph following the bold heading in the book]

Teacher: We still have dikgosi today. [explains point in his own words] What else? I want to hear from someone else.

Student 4: Expansion of Tswana states [exact wording from bold heading in book]

Teacher: [explains as given in the book: some Batswana took control of other groups in their region, to expand control of hunting grounds; doesn't name any specific groups]

Student 5: Decline of local industries [exact wording from bold heading in book]

Teacher: Who can explain?

Student 6: [Reads word-for-word from paragraph following the bold heading in the book] The class was addressing the syllabus objective to "discuss the activities and effects of early European traders/ hunters and missionaries among Batswana." While the teacher explained most points in his own words, he did not offer additional examples, comments, or critiques on what the textbook presented. Student contributions consisted only of words taken verbatim from the textbook.

Because we visited the case study schools during different times in the 2015 school year, not all observed lessons focused on content related to Botswana's national identity. Through teacher interviews and informal conversations, we verified that the teachers' close adherence to 
the written curriculum was typical of their instructional practice. All interviewed teachers claimed that their usual practice was to follow the objectives from the syllabus, using the prescribed textbook to guide their daily instruction. In addition, teachers showed to us their lesson plans, completed daily and signed off on by school leadership, which also closely followed the syllabus and textbooks.

\subsection{Teachers' Perspectives on Curriculum}

In interviews, teachers described myriad ideological and pragmatic reasons for strictly following the curriculum. Many teachers offered perspectives that largely matched the curriculum they were expected to teach. In addition to these ideological explanations for closely following the written curriculum, teachers described practical concerns that encouraged them to implement the syllabus and textbooks as written, even in cases where they might take issue with the curriculum.

This fidelity is not surprising. By and large, teachers in Botswana's government schools are dependent on the central government and Ministry of Education for their own education, sponsorship of their tertiary studies, and employment. Most teachers have come of age in an era of a free basic education, since the government introduced universal, free primary school in 1980 and free junior secondary school in 1987 (Tabulawa, 2011). For students who pass junior secondary school, the government then provides sponsorship for the two-year senior secondary education, and those who achieve high enough marks at this level receive approval and sponsorship from government to study at Teachers' Colleges or the University of Botswana. Teachers have little choice over the program of study at college or university. Not one of the 11 teachers we interviewed described a desire to be a teacher; they based the decision on government sponsorship and future employment opportunities. Teachers have similarly little 
control over what and how they teach once they are employed through the Ministry of Education; as Tabulawa wrote, "The highly specific content leaves absolutely no room for the teacher to determine what to teach" $(2009$, p. 101). Although teachers have a strong union that has ensured they receive fair, timely pay and reasonable leave, teacher morale is generally low due to perceived lack of promotions and salary increases (Mhlauli, 2012). Teachers' indebtedness to government for their education and livelihoods, as well as the limited choice they have over the content areas they teach or how to teach them together comprise factors that decrease the likelihood of their challenging or undermining the official, written curriculum during their classroom practice.

Moreover, when describing how they taught students about Botswana's national identity, teachers frequently echoed the written curriculum in the personal opinions they expressed. More often than not, they upheld the curriculum's approach out of a desire for unity fueled by their own fear of ethnic conflict. A Tswana teacher from Molapo School explained the importance of teaching about kagisano as follows:

You know, we are a nation, yes, formed by different ethnic groups. But kagisano is advocating for us to treat ourselves as Batswana, not identifying ourselves through our ethnic groups.... It is basically bringing the different ethnic groups together to become united and strive for the same goals as a nation. It does help a lot, because if there is unity there's usually less problem of ethnic conflicts, where ethnic groups will think they are better than others. That is tolerance (Interview 13, September 2015).

Another Tswana teacher at Ami School articulated similar fears of ethnic conflict when justifying the need to promote national identity over ethnic identity: "The reason why we have 
this one, nationality over ethnicity, is to promote this united and proud nation, to promote peace. Because if we promote ethnicity there's going to be a problem of tribalism” (Interview 8 , May 2015). A non-Tswana teacher at Metsi School gave the following similar rationale for upholding Setswana's status as a national language:

When I'm with people who do not know me at all, who are from different ethnic groups, then ... I cannot speak [my home language]... because nobody here knows it. I have to speak Setswana because most of us speak Setswana. We speak Setswana as a common language that we share amongst us all. (Interview 4, March 2015)

In fact, most interviewed teachers saw value in promoting Setswana as a common national language, for the sake of unity, although many expressed concern that not allowing other indigenous languages as languages of instruction was disproportionately hindering minority students' school achievement.

Teachers also mentioned the same civic elements of national identity that they taught as part of the curriculum when they described enjoying rights and safety as citizens of Botswana, which they did not perceive other countries in the region offering. Teachers discussed citizens' rights, kagisano, and tolerance for differences in their classroom lessons; in interviews, Tswana and non-Tswana teachers alike described enjoying the right to freedom of movement and employment throughout Botswana and being welcomed, not discriminated against, when outside of their home regions. For example, a Tswana teacher at Molapo School described the value she placed on living in Botswana as follows:

I always tell my classes 'I'm very proud of being a Motswana.' There are lots of things that we see happening around us, especially here in Africa. For example, I 
Prioritizing Unity over Diversity in Botswana

always give an example of apartheid in South Africa. I don't know, if we had gone through that, what would have happened to us.... I am very proud of being a Motswana.... You go from here to [a different ethnic group's region], you are just in Botswana, there is nothing wrong. We don't have problems like in other countries where one ethnic group cannot go into the other area and all that. Ah, no. There is freedom of movement, freedom of speech, freedom of religion. These are things that we have in our country (Interview 13, September 2015).

This teacher's perception that South Africa and other countries in the region experienced more discrimination and fewer freedoms was typical of views that teachers expressed across the interviews. Teachers also described benefitting personally from the free education and health care that they enjoyed in Botswana, as equal rights of all citizens, such as when a non-Tswana teacher in Metsi School said, ...there was also a government [primary] school there in that same town [where she grew up]. So I was there. And then my secondary ... I was still being taken care of by the government. And then my tertiary as well, the government having paid for my tertiary. And for the government to have employed me again. For me, I feel the government has done a lot (Interview 5, March 2015).

Teachers cited crime, xenophobia, and civil wars as social ills common in neighboring countries but absent or extremely rare in Botswana, praising Botswana for some of the same civic values they taught in lessons: tolerance, kagisano, and equal rights.

In no cases did teachers directly oppose curricular content they were expected to teach related to national or ethnic identity, although in a few cases teachers felt the curriculum was 
missing valuable information. One Tswana teacher at Ami School felt strongly that the history curriculum needed to address historical power imbalances between ethnic groups:

One student ... once asked me that question, 'Why is it some cultures in Botswana seem to be much more powerful than others?' ... They don't often ask about it. But I think they have it in their minds. ... But I know it's a burning thing, not even with students, even with adults. It's still burning with them, that, 'Why is it that my culture is not as powerful as that other culture, but we are all Batswana?' As an educator, I feel it's a concept that should also be put into books. Not me being asked and then answer it. It should automatically be in books, whereby if someone asked themselves individually they can still answer themselves again by just looking (Interview 9, May 2015).

This teacher went on to describe how when the student asked him about some groups being more powerful than others, he took the opportunity to discuss the history of 'major' and 'minor' tribes. However, he claimed he did not usually discuss this history because it is not in the official curriculum.

As in the above situation, teachers did not always agree with the written curriculum, as they constructed Botswana's national identity through classroom instruction. Yet even when they disagreed, they described pragmatic considerations that encouraged them to adhere to the curriculum despite private objections. First, in observations, informal conversations, and interviews across the four case study schools, teachers demonstrated great deference to the authority structures governing their schools. When describing different scenarios of how a decision might be taken within his school, a non-Tswana teacher at Ami School explained, 
Sometimes you just compromise after a discussion because somebody with the power you just fear. There's that element of fear, 'Ah, this is the boss.' ... After we have reached a decision, even those who thought otherwise will just support the decision that we took (Interview 7, May 2015).

Citing a similar awareness of the authority structures overseeing her work, one non-Tswana teacher in Metsi School described how, "Teachers are held accountable [for covering the full syllabus] to their senior teachers, then the school head, who is held accountable to the regional office, and ultimately to the Office of the President" (Fieldnotes, 6 March 2015). There was, therefore, very real pressure on teachers to cover the full curriculum in order to avoid blame for students' failure.

Just as teachers did not see how deviating from the established curriculum would serve them well, some expressed concerns about how it would affect students' performance. A nonTswana teacher at Vula School stated,

We teach the prescribed curriculum because this is a transitional stage. We teach them for them to proceed to a higher level only... We teach them so that they can pass their exams and move to the next level. We have to teach them strictly the syllabus because they are tested on that.... it's good to bring anything [supplementary], but learners need to know that this is not part of the objectives. It's just examples. Because they may use that as an answer now, which is not allowed (Interview 11, June 2015).

This teacher's concern for students' exam preparation is well-founded. While all students in Botswana are entitled to education through the end of junior secondary school, only 67 percent progress on to senior secondary school (Botswana Ministry of Education and Skills 
Development, 2015, p. 19). A student's performance in the national exams that the teacher referenced is the sole determining factor in whether that student is offered a place in a government senior secondary school.

Finally, in addition to concerns about how modifying the curriculum might affect their job performance and students' exam results, some teachers expressed a fear of the political ramifications of presenting dissenting views on Botswana's national identity and the integration of ethnic groups. A non-Tswana teacher at Vula School explained,

We don't usually talk about inequality among different groups. We just talk about different groups as equal groups, to avoid conflicts... If we can talk about 'This one is a major tribe, while that one is a minor tribe,' we might be seen [as] fueling tribalism. That's why we don't have anything to do with tribalism at all in our curriculum (Interview 11, June 2015).

Related to the same topic, a Tswana teacher at Ami School acknowledged, "The curriculum is silent [on issues of historical power imbalances between ethnic groups]. But then the curriculum is also political" (Interview 9, May 2015). The same concerns about tribalism that caused some teachers to agree with the written curriculum served to keep other teachers from speaking out when they disagreed.

Teachers in our four case study schools deviated very little from the written social studies curriculum. Their adherence to the construction of national identity found in the curriculum often stemmed from its alignment with their own perspectives. Teachers did express some desire for greater multiculturalism in the curricular construction of Botswana's national identity, as articulated in Vision 2016. Yet out of pragmatic concerns for their job security and their students' performance as well as fears of collective political repercussions these personal views 
almost never led to modifications in their public behaviors, formal classroom instruction oriented toward assimilation.

\section{Discussion and Conclusion}

Fears of ethnically-based conflict contributed to post-Independence educational policies that were assimilationist, promoting a common national identity based on Tswana culture and language. This approach of assimilation in Botswana was a reaction to internal inequalities and geopolitical conditions in neighboring countries that led to the prioritization of the absence of violence, or negative peace. Similar approaches to conflict avoidance through unification around national norms, although different in content, have dominated education in recent post-conflict settings as well, such as in post-apartheid South Africa and in post-genocide Rwanda (e.g., Ferreira, 2016; King, 2014; Teeger, 2015). Temporal distance from conflict, or from the possibility of conflict, is important to consider. Nearly thirty years after Independence, and following decades of pressure from ethnic minority advocates, Botswana's government published a statement of goals, Vision 2016, which marked a clear divergence from seeking national unity through assimilation to Tswana culture (Dryden-Peterson \& Mulimbi, 2017). Vision 2016 articulated Botswana's continuing commitment to building a unified national identity, but its language embodied a shift toward multiculturalism. The rhetorical shifts in Vision 2016 represented a new view of education as a mechanism of positive peace. Our research examined how this rhetorical shift in policy has been reflected in curricula and classroom instruction.

We find that current social studies curriculum as written and taught in Botswana's junior secondary schools largely maintains Tswana dominance in constructing Botswana's national 
Prioritizing Unity over Diversity in Botswana

identity. Some limited passages in the social studies curriculum describe a diversity of cultures within Botswana and promote tolerance of cultural differences, but the content related to this diversity is not essential for students to master and does not address issues of divergent historical understandings, power imbalances, or language rights. The current social studies curriculum integrates multicultural content at what Banks (2001) describes as the most basic level acknowledging some contributions from minority groups without attending to the meanings of these contributions from their group members' perspectives. The emphasis on tolerance of ethnic difference and historical forgetting of power imbalances and inter-ethnic tension does not create a space where intricacies of cultural and linguistic differences can be discussed meaningfully. This approach does not meet Vision 2016's goal for Botswana's schools to "recognize, support, and strengthen" diverse cultures or minority rights advocates' calls to address inequitable student outcomes through recognition in schools.

Yet, at the same time, Botswana's national identity, as constructed in the JSS social studies curriculum, also builds upon civic elements that cut across all ethnic groups, emphasizing rights, principles, and symbols accessible to all Batswana citizens. These civic elements of national identity were clearly quite salient for teachers, particularly as they considered alternatives from Botswana's neighboring countries, such as apartheid, xenophobia, civil war, and limited rights. In interviews, teachers stated that they valued not only these common civic understandings of national identity, but also the Tswana cultural components of national identity, in particular the common language of Setswana, to which they attributed the unity that they so valued. Their appreciation of Botswana's relatively privileged position in the region and of their own indebtedness to the government for rights and resources, including education and employment, along with general pressure to follow authority and not incite tribalism, created an 
environment in which teachers were unlikely to call for greater recognition of minority cultures. Teachers, no matter their own ethnic backgrounds, had little incentive to disrupt the status quo. They expressed fear that working for positive peace might disrupt the negative peace they held dear. From their relatively privileged and powerful positions as teachers, this risk did not seem worth it.

Students, however, might place different value on the components of national identity taught in their social studies classes. On average, a third of these students will not progress even to senior secondary school, and many fewer to tertiary institutions that prepare them for gainful employment. The equal access to education so important to teachers may feel far less relevant to students who do not anticipate reaping tangible benefits from that education. As the educational performance of students in many of the predominantly minority districts lag behind their peers' in historically Tswana districts, equal educational access clearly does not equate with equitable outcomes from schooling.

Multicultural education researchers within and outside of Botswana fault curriculum that encourages assimilation to a dominant group with alienating students from minority cultures and contributing to just such achievement disparities (Banks, 2008; Boikhutso \& Jotia, 2013; Lubinda, 2010; Nyati-Saleshando, 2011; Pansiri \& Jotia, 2013). In these ways, the formal school curriculum's construction of national identity in Botswana may be standing in the way of positive peace. Further research is needed to understand how national identity as taught in schools is learned by students, and how these experiences affect students' sense of identity as both ethnic and national citizens and their ability to access learning and opportunities.

Teachers in our case study schools across ethnically-diverse regions of Botswana accepted an assimilationist approach to national identity in schools out of fear of ethnically- 
based conflict. In the years following Independence, this assimilationist contract between citizens and the state may have been acceptable, trading individual rights for the collective freedom from violence. It may have been a critical component of achieving negative peace. Yet in a period of relatively long and broad absence of violence in Botswana and throughout the region, this contract is due for renegotiation. The continued assimilationist ways in which national identity is constructed in formal curricula and in daily teaching in schools provide evidence both of the need for this renegotiation and the ways in which this renegotiation might take place. In particular, power and opportunity imbalances between ethnic groups may be the more relevant "burning issue" today than the avoidance of violence, especially in a situation of dwindling state resources and rising economic inequalities.

To address these issues and to introduce a more multicultural approach, policies and curriculum in Botswana could recognize minority ethnic groups more fully in several ways. First, social studies curriculum and instruction should make explicit the authorship and perspective of any given a historical narrative, include alternative narratives and their authors, and promote discussions and exercises that encourage students to understand the differing perspectives, as distinct from condemning or accepting them (Carretero, 2011). Second, contemporary issues of discrimination and inequalities between ethnic groups that have arisen from historical events should be acknowledged openly by official curriculum and by teachers, not only when raised by students (Pollock, 2004). Students could discuss such issues through analysis of current events, both local and national, through use of newspapers, radio, television, or the Internet, since at least one of these resources is available even in the most remote schools. Third, language of instruction policies should cease to describe minority languages as problems to be overcome by abandoning them in favor of dominant languages; this would open a debate of 
how schools could include minority languages of instruction as a right for all children and as a resource to foster more equitable learning (see, for example, Piper, Schroeder, \& Trudell, 2016).

Addressing power and opportunity imbalances between ethnic groups through the development of more multicultural approaches in schools will likely require conflict, as individuals and groups negotiate their structural inclusion and access to equitable outcomes. Yet with the foundation of unity that Botswana has established since Independence, this type of conflict stands to productively lay a new foundation of positive peace.

\section{Notes}

${ }^{1}$ Botho is roughly translated as "humane behavior," but is an all-encompassing moral code for how human beings should relate to one another through courtesy, respect, and compassion.

\section{References}

Acemoglu, D., \& Robinson, J. A. (2012). Why nations fail : the origins of power, prosperity and poverty (1st ed.). New York: Crown Publishers.

Anderson, B. R. O. G. (1983). Imagined communities: Reflections on the origin and spread of nationalism. London: Verso.

Banks, J. A. (2008). Diversity, Group Identity, and Citizenship Education in a Global Age. Educational Researcher, 37(3), 129-139. doi:10.3102/0013189x08317501

Banks, J. A. (Forthcoming). Global Migration, Failed Citizenship, and Civic Education. In M. S. Soronso \& M. Suárez-Orozco (Eds.), On Humanitarianism and Mass Migration. Los Angeles; New York: University of California Press; Ross Institute of New York.

Banks, J. A., \& McGee Banks, C. A. (2001). Multicultural education: Issues and perspectives (4th ed.). New York: Wiley.

Bekerman, Z., \& Zembylas, M. (2012). Teaching Contested Narratives: Identity, Memory and Reconciliation in Peace Education and Beyond.

Bellino, M., J., \& Williams, J., H. (2017). (Re)Constructing Memory: Education, Identity, and Conflict. Rotterdam.

Billig, M. (1995). Banal nationalism. London ; Thousand Oaks, Calif.: Sage.

Boikhutso, K., \& Jotia, A. L. (2013). Language identity and multicultural diversity in Botswana. International Journal of Lifelong Education, 32(6), 797-815. doi:10.1080/02601370.2013.814725 
Botswana Ministry of Education and Skills Development. (2015). Botswana: Education for All 2015 National Review. Retrieved from Gaborone:

Brubaker, R. (2009). Ethnicity, Race, and Nationalism. Annual Review of Sociology, 35, 21-42.

Carretero, M. (2011). Constructing patriotism : teaching history and memories in global worlds. Charlotte, N.C.: Information Age Pub.

Christie, P. (2016). Educational change in post-conflict contexts: reflections on the South African experience 20 years later. Globalisation, Societies and Education, 14(3), 434446. doi:10.1080/14767724.2015.1121379

Cook, A., \& Sarkin, J. (2010). Is Botswana the Miracle of Africa? Democracy, the Rule of Law, and Human Rights Versus Economic Development. 19, 453-977.

Denbow, J. R., \& Thebe, P. C. (2006). Culture and customs of Botswana. Westport, Conn.: Greenwood Press.

Dryden-Peterson, S., \& Mulimbi, B. (2017). Pathways Toward Peace? Negotiating National Unity and Ethnic Diversity through Education in Botswana. Comparative Education Review.

Erikson, E. H. (1968). Identity, youth, and crisis (1st ed.). New York: W. W. Norton.

Ferreira, A. (2016). 'A sort of black and white past and present thing': high school students' subject positions on South Africa's recent past. Race Ethnicity and Education, 19(6), 1247-1261. doi:10.1080/13613324.2015.1095175

Freedman, S. W., Weinstein, H. M., Murphy, K., \& Longman, T. (2008). Teaching History after Identity-Based Conflicts: The Rwanda Experience. Comparative Education Review, 52(4), 663-690.

Gaertner, S. L., \& Dovidio, J. F. (2000). Reducing intergroup bias : the common ingroup identity model. Philadelphia, PA: Psychology Press.

Galston, W. A. (2001). Political Knowledge, Political Engagement, and Civic Education. Annual Review of Political Science, 4(1), 217-234.

Galtung, J. (1969). Violence, Peace, and Peace Research. Journal of Peace Research, 3, $167-$ 191.

Gaolathe, T., Wirth, K. E., Holme, M. P., Makhema, J., Moyo, S., Chakalisa, U., . . Lockman, S. (2016). Botswana's progress toward achieving the 2020 UNAIDS 90-90-90 antiretroviral therapy and virological suppression goals: a population-based survey. The lancet. HIV, 3(5), e221. doi:10.1016/S2352-3018(16)00037-0

Gapa, A. (2017). Identity Management: The Creation of Resource Allocative Criteria in Botswana. African Studies Quarterly, 17(1), 1-22.

Gewald, J.-B. (1999). Herero heroes : a socio-political history of the Herero of Namibia, 18901923. Athens: Ohio University Press.

Gossett, C. W. (1986). The Civil Service in Botswana: Personnel Policies in Comparative Perspective (Public Policy, Southern Africa). (8608147 Ph.D.), Stanford University, Ann Arbor. Retrieved from http://search.proquest.com.ezpprod1.hul.harvard.edu/docview/303526618?accountid=11311 ProQuest Dissertations \& Theses Global database.

Government of Botswana. (2008). The Repeal of the Chieftainship Act. Gaborone: Government of Botswana Retrieved from http://www.gov.bw/en/Ministries-Authorities/Ministries/Ministry-of-Local-Government-MLG1/Publications/Reports/.

Gozik, N. J. (2012). Teaching national and regional cultures: the role of teacher identities in Martinique. Compare: A Journal of Comparative \& International Education, 42(1), 5-25. 
Gulbrandsen, Ø. (2012). The state and the social : state formation in Botswana and its precolonial and colonial genealogies. New York: Berghahn Books.

Institute for Economics and Peace. (2016). Positive Peace Report 2016: A Compilation of the Leading Research on Positive Peace and Resilience. Sydney: Institute for Economics and Peace.

Institute for Economics and Peace. (2017). Global Peace Index 2017: Measuring Peace in a Complex World. Syndey: Institute for Economics and Peace.

Janson, T., \& Tsonope, J. (1991). Birth of a national language : the history of Setswana. Gaborone, Botswana: Heinemann Botswana : National Institute of Development Research and Documentation.

Jones, F. L., \& Smith, P. (2001). Diversity and commonality in national identities: An exploratory analysis of cross-national patterns. Journal of Sociology, 37(45-63).

King, E. (2014). From classrooms to conflict in Rwanda. New York: Cambridge University Press.

Kunovich, R. M. (2009). The Sources and Consequences of National Identification. American Sociological Review, 74(4), 573-593.

Kymlicka, W., \& Norman, W. J. (2000). Citizenship in diverse societies: Issues, Contexts, Concepts. In W. J. Norman \& W. Kymlicka (Eds.), Citizenship in diverse societies (pp. 1-41). Oxford ;New York: Oxford University Press.

Leith, J. C. (2005). Why Botswana prospered. Montreal: McGill-Queen's University Press.

Lerch, J. C., Russell, S. G., \& Ramirez, F. O. (2017). Wither the Nation-State? A Comparative Analysis of Nationalism in Textbooks. Social Forces, 96(1), 153-180. doi:10.1093/sf/sox049

Lubinda, J. (2010). Promoting multiculturalism and intercultural dialogue through institutions and initiatives of civil society organizations in Botswana. Journal of Multicultural Discourses, 5(2), 121-130.

Malley-Morrison, K. (2013). International Handbook of Peace and Reconciliation. New York, NY.

Mhlauli, M. B. (2012). The paradox of teaching citizenship education in Botswana primary schools. European Journal of Educational Studies, 1(2).

Minority Voices Newsroom. (2010). Botswana: Lentswe La Batswapong. Retrieved from http://www.minorityvoices.org/news.php/en/308/botswana-lentswe-la-batswapong

Moswang, K., Tsayang, G. T., \& Rampha, L. (2010). Social studies form 2: Learner's book. Gaborone: Collegium.

Moyo, D. (2009). Dead aid : why aid is not working and how there is a better way for Africa (1st American ed.). New York: Farrar, Straus and Giroux.

Niens, U., \& Chastenay, M. H. (2008). Educating for Peace? Citizenship Education in Quebec and Northern Ireland. Comparative Education Review, 52(4), 519-540. doi:10.1086/591296

Novelli, M., \& Smith, A. (2011). The Role of Education in Peacebuilding: A synthesis report of findings from Lebanon, Nepal and Sierra Leone. New York: UNICEF.

Nyamnjoh, F. B. (2002). Local Attitudes towards Citizenship and Foreigners in Botswana: An Appraisal of Recent Press Stories. Journal of Southern African Studies, 28(4), 755-775. doi:10.1080/0305707022000043502

Nyati-Ramahobo, L. (2006a). Language policy, cultural rights and the law in Botswana. Contributions to the Sociology of Language, 92, 285-304. 
Nyati-Ramahobo, L. (2006b). Language policy, cultural rights and the law in Botswana. Contributions to the Sociology of Language, 92(285-304).

Nyati-Ramahobo, L. (2006c). The long road to multilingual schools in Botswana. In O. Garcia, T. Skutnabb-Kangas, \& M. E. Torres-Guzman (Eds.), Imagining multilingual schools: Languages in education and glocalization (pp. 200-222). Tonawanda, NY: Multilingual Matters, Ltd.

Nyati-Saleshando, L. (2011). An Advocacy Project for Multicultural Education: The Case of the Shiyeyi Language in Botswana. International Review of Education, 57(5-6), 567-582.

Pansiri, N. O. (2012). Ethnocultural identities and school retention: The case of rural ethnic minorities in Botswana. AlterNative: An International Journal of Indigenous Peoples(8), 3.

Pansiri, N. O., \& Jotia, A. (2013). Multicultural Education: The Missing Link in Botswana Education Policy. European Journal of Educational Studies, 5(1), 101-110.

Paulson, J. (2015). "Whether and How?" History Education about Recent and Ongoing Conflict: A Review of Reseach. Journal on Education in Emergencies, 1(1), 14-47.

Pingel, F. (2010). The Power of the Curriculum. In K. M. Cahill (Ed.), Even in chaos : education in times of emergency (1st ed., pp. 109-135). New York: Fordham University Press; Center for International Humanitarian Cooperation.

Piper, B., Schroeder, L., \& Trudell, B. (2016). Oral reading fluency and comprehension in Kenya: reading acquisition in a multilingual environment. Journal of Research in Reading, 39(2), 133-152. doi:10.1111/1467-9817.12052

Pollock, M. (2004). Colormute : race talk dilemmas in an American school. Princeton: Princeton University Press.

Presidential Task Group for a Long-Term Vision for Botswana. (1997). Vision 2016: Long-Term Vision for Botswana, Towards Prosperity For all. Gaborone: Government Printing and Publishing Services.

Republic of Botswana. (1966a). Constitution of Botswana. Gaborone: Government Printer. Republic of Botswana. (1966b). Constitution of Botswana. Gaborone.

Republic of Botswana. (1977). Education for kagisano: Report of the national commission on education. Gaborone: Government Printer.

Republic of Botswana. (1994). The Revised National Policy on Education. Gaborone: Republic of Botswana.

Republic of Botswana. (2000). Report of the Presidential Commission of Inquiry into Sections 77, 78, and 79 of the Constitution of Botswana. Gaborone: Government Printer.

Republic of Botswana. (2009). National development plan 10, 2009-2016. Gaborone: Government Printer.

Republic of Botswana. (2010). Three-Year Junior Secondary Syllabus. Retrieved from Gaborone:

Scanlon, C. (2002). Educating For Peace: Politics and Human Rights in Botswana. PCD, 1(1). doi: $10.7246 / 0105$

Selander, S. (1990). Towards a theory of pedagogic text analysis. Scandinavian Journal of Educational Research, 34(2), 143-150.

Selolwane, O. (2004). Ethnic structure, inequality and governance of the public sector in Botswana. Retrieved from Geneva:

Tabulawa, R. (2009). Education Reform in Botswana: Reflections on Policy Contradictions and Paradoxes. Comparative Education, 45(1), 87-107. 
Tabulawa, R. (2011). The rise and attenuation of the basic education programme (BEP) in Botswana: A global-local dialectic approach. International Journal of Educational Development, 31(5), 433-442.

Teeger, C. (2015). "Both Sides of the Story": History Education in Post-Apartheid South Africa. American Sociological Review, 80(6), 1175-1200. doi:doi:10.1177/0003122415613078

Tsayang, G. T., Rampha, L., \& Mpitse, D. L. (2009). Social studies form 1: Learner's Book. Gaborone: Collegium.

UNICEF. (2013). Botswana: Statistics. Retrieved from New York: http://www.unicef.org/infobycountry/botswana statistics.html

United Nations Development Programme. (2016a). Briefing note for countries on the 2016 Human Development Report: Botswana. New York: UNDP.

United Nations Development Programme. (2016b). Human Development Report 2016: Human Development for Everyone. New York: UNDP.

Werbner, R. P. (2004). Reasonable radicals and citizenship in Botswana : the public anthropology of Kalanga elites. Bloomington: Indiana University Press. 
Table 1

Characteristics of Case Study Schools

\begin{tabular}{lcccc} 
School Name & Metsi & Ami & Vula & Molapo \\
\cline { 2 - 4 } Region & southeast & northwest & northeast & southeast \\
City size & midsize & small & small & large
\end{tabular}

Surrounding community ethnic composition

$\begin{array}{lcccc}\begin{array}{l}\text { numerical } \\ \text { majority }\end{array} & \begin{array}{c}\text { Bakgatla } \\ \text { (Tswana) }\end{array} & \text { Wayeyi } & \text { Kalanga } & \begin{array}{c}\text { various } \\ \text { Tswana }\end{array} \\ \begin{array}{l}\text { numerical } \\ \text { minorities }\end{array} & \begin{array}{c}\text { sizeable Herero } \\ \text { various } \\ \text { minorities }\end{array} & \begin{array}{c}\text { Hambukushu, } \\ \text { few Herero, } \\ \text { KhoiSan, } \\ \text { Tswana }\end{array} & \begin{array}{c}\text { Bangwato } \\ \text { (Tswana) }\end{array} & \begin{array}{c}\text { wide variety of } \\ \text { minorities \& } \\ \text { non-citizens }\end{array}\end{array}$

\section{Student ethnic composition}

$\begin{array}{lcccc}\begin{array}{l}\text { numerical } \\ \text { majority }\end{array} & \begin{array}{c}\text { Bakgatla } \\ \text { (Tswana) }\end{array} & \text { Wayeyi } & \text { Kalanga } & \begin{array}{c}\text { various } \\ \text { Tswana }\end{array} \\ \begin{array}{l}\text { numerical } \\ \text { minorities }\end{array} & \begin{array}{c}\text { wide variety, } \\ \text { very few }\end{array} & \begin{array}{c}\text { Herero, } \\ \text { KhoiSan, few } \\ \text { Tswana }\end{array} & \begin{array}{c}\text { Bangwato } \\ \text { (Tswana) }\end{array} & \begin{array}{c}\text { karious } \\ \text { Kinorities } \\ \text { few non- } \\ \text { citizens }\end{array}\end{array}$

\section{Staff ethnic composition}

regular

teachers

\begin{tabular}{lcccc} 
managem't & $\begin{array}{c}\text { same as regular } \\
\text { teachers }\end{array}$ & $\begin{array}{c}\text { higher } \\
\text { proportion } \\
\text { from northwest } \\
\text { \# students }\end{array}$ & $\begin{array}{c}\text { higher } \\
\text { proportion of } \\
\text { Kalanga }\end{array}$ & $\begin{array}{c}\text { same as regular } \\
\text { teachers }\end{array}$ \\
boarding & $400-600$ & $800-1,000$ & $400-600$ & $800-1000$ \\
\hline
\end{tabular}


Table 2

Interview Participants

\begin{tabular}{lllc}
\hline $\begin{array}{l}\text { Interview } \\
\text { No. }\end{array}$ & Role or School & $\begin{array}{l}\text { Ethnic } \\
\text { background }^{a}\end{array}$ & $\begin{array}{l}\text { \# years } \\
\text { teaching }\end{array}$ \\
\hline 1 & $\begin{array}{l}\text { Social Studies syllabus } \\
\text { committee member }\end{array}$ & & \\
& $\begin{array}{l}\text { Social Studies textbook } \\
\text { author }\end{array}$ & & \\
& Metsi School teacher & Tswana & $>10$ \\
3 & Metsi School teacher & non-Tswana & $>5$ \\
4 & Metsi School teacher & non-Tswana & $>5$ \\
5 & Ami School teacher & non-Tswana & $>10$ \\
6 & Ami School teacher & non-Tswana & $>5$ \\
7 & Ami School teacher & Tswana & $<5$ \\
8 & Ami School teacher & Tswana & $>5$ \\
9 & Ami School teacher & Tswana & $<5$ \\
10 & Vula School teacher & non-Tswana & $>10$ \\
11 & Vula School teacher & non-Tswana & $>5$ \\
12 & Molapo School teacher & Tswana & $>10$ \\
13 & Tswa
\end{tabular}

${ }^{a}$ We describe each teacher as "Tswana" if he or she self-identified as a member of one of the eight Tswana ethnic groups recognized in the Constitution, or "non-Tswana" if he or she selfidentified as one of the groups not recognized in the Constitution. We do not provide more specific ethnic identifications to protect the identities of the teachers.

${ }^{\mathrm{b}}$ Although Molapo School was a large school, teachers at this school were much more reluctant to participate in interviews. Only one social studies teacher consented to be interviewed, although all sampled teachers allowed us to observe their classes. 
Table 3

Instructional Content Observed in Social Studies Lessons

\begin{tabular}{|c|c|c|c|c|c|c|c|c|}
\hline & $\mathbf{n}$ & $\begin{array}{l}\text { from } \\
\text { curric. }\end{array}$ & $\begin{array}{l}\text { explain } \\
\text { text }\end{array}$ & $\begin{array}{c}\text { add'l } \\
\text { example }\end{array}$ & $\begin{array}{c}\text { new } \\
\text { concept }\end{array}$ & $\begin{array}{l}\text { comment on } \\
\text { curric. }\end{array}$ & non-curric. & $\begin{array}{l}\text { reflect on } \\
\text { learning }\end{array}$ \\
\hline Metsi School (southeast) & 7 & $46.0 \%$ & $11.3 \%$ & $1.8 \%$ & $3.0 \%$ & $2.1 \%$ & $22.6 \%$ & $13.1 \%$ \\
\hline Ami School (northwest) & 8 & $49.9 \%$ & $18.1 \%$ & $11.4 \%$ & $4.6 \%$ & $0.6 \%$ & $8.0 \%$ & $7.4 \%$ \\
\hline Vula School (northeast) & 6 & $56.7 \%$ & $18.1 \%$ & $9.5 \%$ & $0.7 \%$ & $0.0 \%$ & $8.8 \%$ & $6.3 \%$ \\
\hline Molapo School (southeast) & 4 & $43.7 \%$ & $28.1 \%$ & $3.8 \%$ & $4.4 \%$ & $0.0 \%$ & $16.4 \%$ & $3.6 \%$ \\
\hline Total & 25 & $49.5 \%$ & $19.0 \%$ & $7.2 \%$ & $3.2 \%$ & $0.6 \%$ & $13.1 \%$ & $7.4 \%$ \\
\hline $\begin{array}{l}\text { utterances by teachers } \\
\text { questions by teachers }\end{array}$ & $\begin{array}{l}56.5 \% \\
88.5 \%\end{array}$ & & & & & & & \\
\hline
\end{tabular}

Note: Types of content: directly from the curriculum, an explanation of the curriculum, additional examples, new or contradictory content, judgment on the curriculum, non-content related, or comment on the learning process; utterances by teachers: percentage of teacher statements or questions, compared to all students; questions by teachers: percentages of all questions asked that were posed by the teacher, compared to all students 